\title{
Variation and Population Structure at Enzyme Gene Loci in Araucaria angustifolia (Bert.) 0. Ktze
}

\author{
By V. A. Sousa ${ }^{1}$, I. P. Robinson ${ }^{2}$ and H. H. HATTEMER ${ }^{3}$
}

(Received $18^{\text {th }}$ August 2003)

\begin{abstract}
We describe alloenzyme variation in A. angustifolia populations of three separate geographical areas in southern Brazil. The genetic structure of populations was examined in seedtrees, embryos and effective pollen. Seven out of 24 enzyme loci were polymorphic. The average number of alleles per locus (24 loci) was 1.54 , with 2.44 alleles per polymorphic locus. Mean expected and observed heterozygosities at the polymorphic loci were $H_{e}=0.128$ and $H_{o}=0.132$ for seed-trees, and $H_{e}=0.142$ and $H_{0}=0.161$ for embryos. All measures of genetic variability were highest in the most northern populations. Differences among localities explained $84.14 \%$ and $92.06 \%$ of the total genetic diversity in embryos and seed trees, respectively. Sex ratio was 1:1 in almost all populations. Female and male gene pools differed in allele frequencies, most significantly at loci 6 $P g d h-B$ and $S k d h-B$. This explains the excess of heterozygotes detected among embryos. No inbreeding or excess of heterozygotes was detected among adult seed trees. Genetic variation in $A$. angustifolia revealed a latitudinal gradient.
\end{abstract}

Key words: Paraná pine, alloenzymes, genetic variation, differentiation of populations, paleohistory.

\section{Introduction}

The Araucariaceae is an ancient conifer family. In South America, the Araucariaceae are represented by two native species, Araucaria araucana (Molina) K. Koch and Araucaria angustifolia (Bert.) O. Kuntze. The Araucaria forest of the southern highlands in Brazil is named after Araucaria angustifolia. At the beginning of the twentieth century, Araucaria angustifolia, or Paraná pine, formed dense forests covering $184,000 \mathrm{~km}^{2}$ in southern Brazil (GUBERT FilHo, 1989). A century later, the remnants of these forests are highly fragmented and threatened to extinction. A. angustifolia is a dioecious species. The insulation of the forest fragments is of particular concern because both seed and pollen dispersal patterns suggest that gene flow in A. angustifolia is less widespread than in other conifers (SOUSA and HATTEMER, 2003).

The present geographic range of $A$. angustifolia extends from $19^{\circ} 15^{\prime} \mathrm{S}$ to $31^{\circ} 30^{\prime} \mathrm{S}$, and from $41^{\circ} 30^{\prime} \mathrm{W}$ to $54^{\circ} 30^{\prime} \mathrm{W}$ (HUECK, 1966 ; FÄHSER, 1981). The species distribution was much wider in the Late Quaternary, including a substantial fossil record in southern and central Brazil (Kershaw and McGlone, 1995; KershaW and WAGSTAFF, 2001). In the present climate, natural Araucaria forests are found predominantly between 500 to 1,500 meters (up to 2,300 meters) above the sea level.

Mattos (1965), Gurgel and Gurgel Filho (1965), and Reitz and KLEIN (1966) described geographical races of A. angustifolia. In addition to geographical variation, Araucaria forests differ significantly in species composition. The natural regeneration of A. angustifolia becomes gradually inhibited as the forest

\footnotetext{
1) Embrapa Florestas, Caixa Postal 319, C.E.P. 83.411-000 Colombo-PR, Brazil

2) Biological Sciences, State University of New York, Albany, 12222 New York, United States of America

3) Institut für Forstgenetik und Forstpflanzenzüchtung der Universität Göttingen, Büsgenweg 2, D-37077 Göttingen, Germany
}

is invaded by tropical rainforest species, which are better adapted to present climate (KLEIN, 1960; REITZ and KLEIN, 1966; KLEIN, 1990).

Genetic differences among populations of A. angustifolia were first demonstrated in provenance trials conducted in tree improvement programs (GURGEL and GuRGel Filho, 1965; KaGeyama and JACOB, 1980; Monteiro et al., 1982; GianNotTI et al., 1982; SHIMIZU, 1999). Isozyme variability was examined in a relict population of $A$. angustifolia situated in the Iguaçu National Park (Paraná State), at the edge of the southwestern range of the species (SHimizu et al., 2000), and in nine natural populations of $A$. angustifolia in Santa Catarina State (AUler et al., 2002). At the DNA level, MAZZA (1997) detected differences between provenances using RAPD, and HAMPP et al. (2000) found geographic variation in a cloned polymorphic DNA sequence. In the present report we describe the genetic structure of different kinds of A. angustifolia populations, within three localities, comparing seed tree, embryo and pollen gene pools.

\section{Material and Methods \\ Description of populations}

Populations were sampled in three major conservation sites for Araucaria forests. Campos do Jordão (22 ${ }^{\circ} 44^{\prime} \mathrm{S}, 43^{\circ} 44^{\prime} \mathrm{W}$; 1800 meters above sea level, in São Paulo State) is a State Park. Irati $\left(25^{\circ} 30^{\prime} \mathrm{S}, 50^{\circ} 36^{\prime} \mathrm{W}, 880\right.$ meters above sea level, in Paraná State) and Caçador ( $26^{\circ} 50^{\prime} \mathrm{S}, 51^{\circ} 00^{\prime} \mathrm{W}, 1100$ meters above sea level, in Santa Catarina State) are National Parks. The vegetation in the Campos do Jordão park consists of native grassland and forest. The park includes 8,223 hectares, 5,655 hectares of which are forests (FAVRIN, 1985). Podocarpus lambertii and Podocarpus sellowii are common species in the plant community, which shows abundant natural regeneration of $A$. angustifolia. The forest in Irati covers 3,495 ha (IBAмA, 2000) and is rich in Lauraceae species, characteristic of the Araucaria-Ocotea community. Local smaller remnants range from pioneer to late transition forest stages (GUBERT FILHO, 1989). The forest in Caçador covers 1,600 ha. The large emergent $A$. angustifolia trees dominate in the upper canopy stratum, but the species shows very low natural regeneration (CROCE, 1991). Ocotea porosa, O. pretiosa, Cedrela fissilis, Sloanea lasiocoma, and other late succession species characterize the main forest and local smaller remnants. The climate in the three areas is subtropical mesothermic. February is the warmest month $\left(17-22^{\circ} \mathrm{C}\right)$ and July is the coldest $\left(8-12^{\circ} \mathrm{C}\right)$, with absolute minimum temperatures reaching below $0{ }^{\circ} \mathrm{C}$ in all three localities. Rainfall ranges between 1,500 to $2,000 \mathrm{~mm}$. The following populations were sampled in the parks: the large undisturbed main forest (LF); an exploited forest section (EF) submitted to selective logging in the past; forest islands (FI) surrounding the main site in Irati and in Caçador; and a 37 years old $A$. angustifolia plantation (PL), in Irati, established with seeds collected in the main forest. The size of the sampling plots is shown in Table 1. A. angustifolia trees with diameter equal to or larger than $10 \mathrm{~cm}$ were mapped and classified as males, 
Table 1. - Number of trees counted in the sampling plot, sex and diameter (d.b.h.) of trees, and $\chi^{2}$ test for 1:1 sex ratio hypothesis.

\begin{tabular}{|c|c|c|c|c|c|c|c|c|c|c|c|c|c|c|}
\hline \multirow[t]{2}{*}{ Locality } & \multirow[t]{2}{*}{ Population } & \multirow[t]{2}{*}{$\begin{array}{l}\text { Area } \\
\text { (ha) }\end{array}$} & \multicolumn{2}{|c|}{ Males } & \multicolumn{2}{|c|}{ Females } & \multicolumn{2}{|c|}{$\begin{array}{c}\text { Non- } \\
\text { reproducing }\end{array}$} & \multirow[t]{2}{*}{ Total } & \multirow{2}{*}{$\begin{array}{c}\text { Average } \\
\text { d.b.h. } \\
\varnothing\end{array}$} & \multicolumn{4}{|c|}{$\begin{array}{l}\text { Sex ratio } \\
\text { (\% trees) }\end{array}$} \\
\hline & & & $\mathrm{N}$ & $\varnothing$ & $\mathrm{N}$ & $\varnothing$ & $\mathrm{N}$ & $\varnothing$ & & & Male & Female & NR & $\chi^{2}$ \\
\hline \multirow[t]{2}{*}{ C. Jordão } & Large Forest (LF) & 1.0 & 52 & 39.83 & 40 & 38.96 & 112 & 13.00 & 204 & 25.09 & 25.49 & 19.61 & 54.90 & 1.57 \\
\hline & Exploited Forest (EF) & 1.0 & 40 & 42.50 & 64 & 37.50 & 62 & 17.50 & 166 & 31.30 & 24.10 & 38.55 & 37.35 & $5.54^{*}$ \\
\hline \multirow{5}{*}{ Irati } & Large Forest (LF) & 1.0 & 26 & 46.06 & 48 & 48.88 & 35 & 21.20 & 109 & 39.30 & 23.85 & 44.04 & 32.11 & $6.54^{*}$ \\
\hline & Forest Island (FI-1) & 0.5 & 13 & 48.40 & 14 & 51.10 & 12 & 23.00 & 39 & 42.10 & 33.33 & 35.90 & 30.77 & 0.04 \\
\hline & Forest Island (FI-2) & 0.3 & 4 & 46.60 & 7 & 46.40 & 20 & 13.80 & 31 & 25.40 & 12.90 & 22.58 & 64.52 & 0.82 \\
\hline & Exploited Forest (EF) & 0.3 & 6 & 45.90 & 4 & 50.80 & 7 & 11.10 & 17 & 32.70 & 35.29 & 23.53 & 41.18 & 0.40 \\
\hline & Plantation (PL) & 0.3 & 24 & 35.80 & 37 & 35.20 & 25 & 17.60 & 86 & 29.96 & 27.91 & 43.02 & 29.07 & 2.77 \\
\hline \multirow{6}{*}{ Caçador } & Large Forest (LF) & 1.0 & 39 & 70.10 & 31 & 87.80 & 2 & 29.30 & 72 & 77.00 & 54.17 & 43.06 & 2.78 & 0.91 \\
\hline & Forest Island (FI-1) & 0.3 & 9 & 65.00 & 16 & 69.60 & 0 & $-\cdots$ & 25 & 68.00 & 36.00 & 64.00 & --- & 1.96 \\
\hline & Forest Island (FI-2) & 0.3 & 12 & 62.90 & 16 & 88.50 & 3 & 35.30 & 31 & 73.50 & 38.71 & 51.61 & 9.68 & 0.57 \\
\hline & Forest Island (FI-3) & 0.3 & 11 & 70.10 & 11 & 76.71 & 1 & 32.80 & 23 & 71.60 & 47.83 & 47.83 & 4.35 & 0.00 \\
\hline & Forest Island (FI-4) & 0.3 & 10 & 90.50 & 7 & 80.40 & 14 & 43.60 & 31 & 67.10 & 32.26 & 22.58 & 45.16 & 0.53 \\
\hline & Exploited Forest (EF) & 0.3 & 11 & 70.60 & 5 & 65.80 & 1 & 7.90 & 17 & 65.50 & 64.71 & 29.41 & 5.88 & 2.25 \\
\hline Total & & & 257 & 57.90 & 300 & 59.60 & 294 & 21.20 & 851 & & 30.20 & 35.25 & 34.55 & 3.32 \\
\hline
\end{tabular}

$\varnothing=$ average d.b.h. $(\mathrm{cm}) ; \mathrm{N}=$ number of trees; $\mathrm{NR}=$ non-reproducing; $* \mathrm{P}<0.05$.

females, and non-reproducing trees (young sexually immature individuals and mature trees not producing strobili in 1998). The expected 1:1 sex ratio within each population was verified using the $\chi^{2}$ test.

\section{Isozyme electrophoresis}

Enzyme extraction, starch-gel electrophoresis, and the mode of inheritance of $A$. angustifolia isozymes are described in Sousa et al. (2002). The megagametophyte and the embryo were examined in 20 seeds in each of 35 trees in the populations of Campos do Jordão; and in 8 seeds, in each of 10 trees, in all other populations (total $=2,280$ seeds). The genotype of the seed tree was inferred from the type and frequencies of the alleles present in its megagametophytes. The genotype of the effective pollen grain was inferred from the comparison of paired megagametophyte-embryo zymograms. Effective pollen refers to the pollen grains that participated in fertilization events producing seeds. Thirteen isozyme systems were examined.

\section{Descriptors of genetic variation and differentiation}

The allelic structure of populations is described by the number of alleles per examined locus $(A / L)$; the percentage of polymorphic loci $(P P L)$; the genetic diversity index $v$ (GREGORIUS, 1987), which is equivalent to the effective number of alleles (CROW and KIMURA, 1970); and the gametic diversity index $v_{\text {gam }}$ (GREGORIUS, 1978), which measures the populations' potential for producing genetically diverse gametes. At the genotypic level, variation is described by the observed $\left(H_{o}\right)$ and expected $\left(H_{e}\right)$ heterozygosities defined by NEI (1973). In large samples, $H_{e}$ is comparable to the total differentiation $\delta_{T}$ defined by GREGORIUS (1978). Genetic differences between populations were examined in dendrograms constructed with the genetic distances $D$ (NEI, 1972) and $d_{o}$ (GREgorius, 1974). The differentiation of populations was described in seed-trees, embryos and pollen gene pools, for individual and pooled loci, using the parameters $D_{j}$ and $\delta$ (Gregorius, 1985; Gregorius and ROBERDS, 1986) and interpreted using the $F$-statistics (WRIGHT, $1951,1965) . D_{j}$ corresponds to the proportion of genetic types (alleles, gametes, or genotypes) of a population that is not shared by other populations. The parameter $\delta$ represents the average differentiation present in the entire collection. The relationship between the two parameters is illustrated by snail diagrams, where the radii of the sectors are $D_{j}$ and the radius of the central circle is $\delta$. The calculations were performed using
GSED version 1.1 (GILLET, 1998) and BIOSYS-2 (SWOFFORD and SELANDER, 1997).

\section{Results}

Genotypic variation of seed-trees and progenies within populations

Twenty-four isozyme loci were identified, seven were polymorphic at the $95 \%$ criterion: Got- $B$ (3 alleles), Got-C (2 alleles), Pgm-A (2 alleles), $M d h-B$ (2 alleles), $S k d h-A$ (2 alleles), $S k d h-B$ (2 alleles), and 6-Pgdh-B (3 alleles). Fifteen loci (AapA, Gdh-A, Lap-A, Lap-B, Idh-A, Pgi-A, G6-Pdh-A, Mnr-A, Nadh-A, Nadh-B, Mdh-A, Mdh-C, Mdh-D, Pgm-B and 6-Pgdh$A$ ) were monomorphic. Two loci, Got-A and Pgi-B, were excluded from the variation measures except for $A / L, A / P$ and $P P L$. The zymograms of heterozygotes for Got-A ( 3 alleles) had no consistent resolution and the polymorphism at Pgi-B (3 alleles) was below 1\%. All together, 37 different Araucaria alloenzymes were identified (SousA et al., 2002). Measures of genetic variation in seed-trees and in their progenies, in the 13 Araucaria populations, are shown in Table 2 . The average number of alleles per locus $(A / L$ at 24 loci) at the species level is 1.54 , with 2.44 alleles per polymorphic locus. The mean heterozygosities of the 13 populations, at the seven polymorphic loci, were $H_{e}=$ 0.128 and $H_{o}=0.132$ for seed-trees; and $H_{e}=0.142$ and $H_{o}=$ 0.161 , for embryos.

\section{Differentiation among populations}

The distribution of the genetic variance in A. angustifolia is shown in Table 3. Comparisons of hierarchical levels of diversity are expressed as variance components, percentage of total variance, and $F$-statistics. Variance components and $F$-statistics revealed the same trends. Small negative variance components, occasionally obtained with the BIOSYS-2 program, were disconsidered. The most important source of variation is localities. Differences among localities explain $84.14 \%$ and $92.06 \%$ of the total heterozygosity present in embryos and seed-trees, respectively. Other comparisons shown in Table 3 consider only embryo genotypes. The two kinds of management had no significant effect upon heterozygosity in the samples from Campos do Jordão and Irati, but explained almost $4.96 \%$ of it in Caçador. The comparison between large forests and forest islands shows that forest size determined $4.09 \%$ of the total heterozygosity in Irati and $7.40 \%$ in Caçador. Finally, the large forest and the plantation in Irati showed similar heterozygosities. 
Table 2. - Genetic variation in seed-trees and their progenies (embryos) in 13 populations of Araucaria angustifolia. Average number of alleles per locus $(A / L)$, percentage polymorphic loci $(P P L)$, allelic diversity $(v)$, gametic diversity $\left(v_{\text {gam }}\right)$ and heterozygosities $\left(H_{o}\right.$ and $\left.H_{e}\right)$.

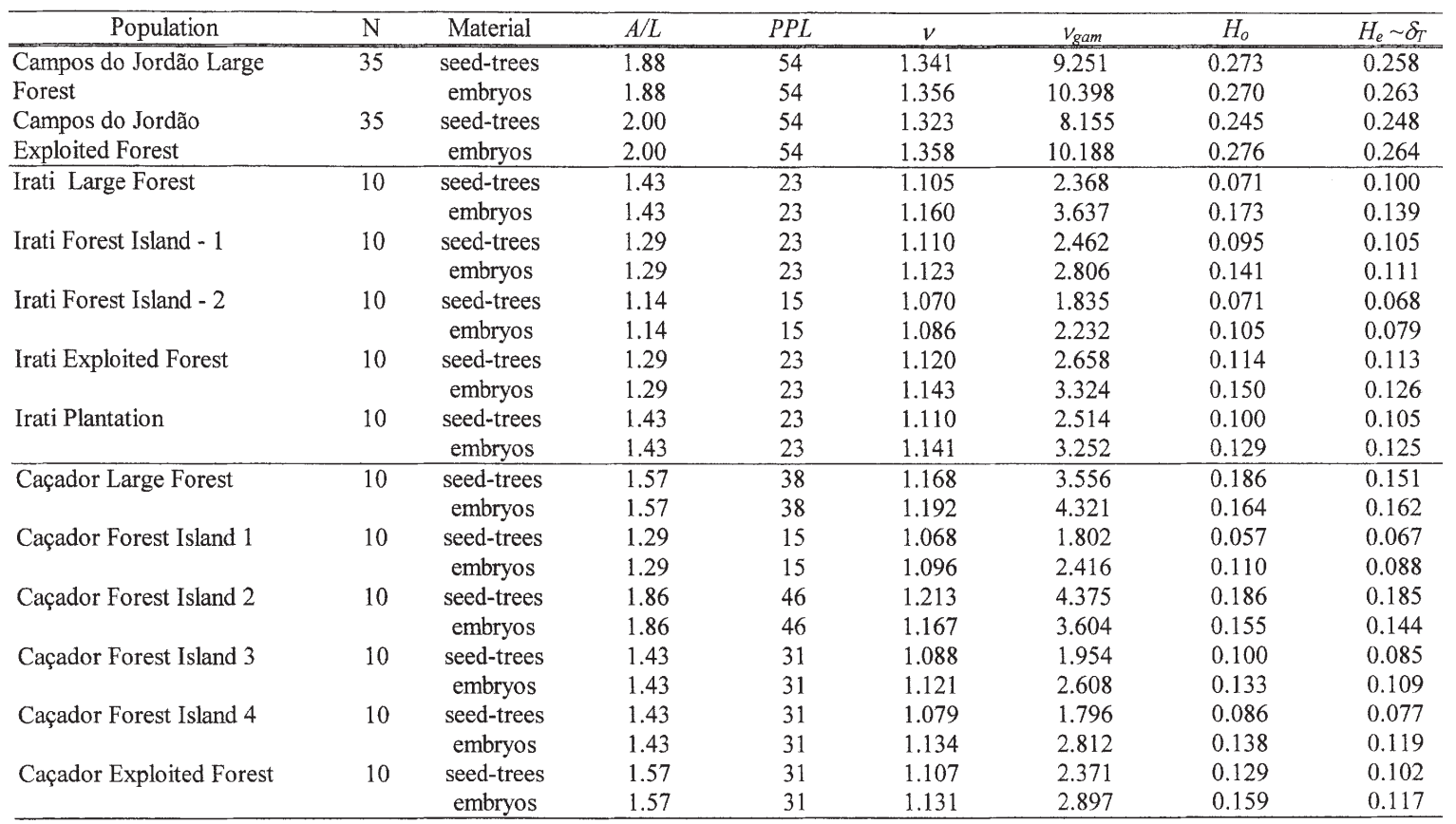

Table 3. - Variance components and $F$-statistics combined across loci. X and Y represent the hierarchical levels being compared.

\begin{tabular}{|c|c|c|c|c|}
\hline Comparison & $\mathrm{X}-\mathrm{Y}$ & $\begin{array}{l}\text { Variance } \\
\text { component }\end{array}$ & $\begin{array}{l}\% \text { of total } \\
\text { variance }\end{array}$ & $F_{X Y}$ \\
\hline \multicolumn{5}{|l|}{ a) Populations vs. Localities } \\
\hline \multirow{3}{*}{ Embryos } & Populations - Localities & 0.01606 & 15.86 & 0.016 \\
\hline & Localities - Total & 0.08519 & 84.14 & 0.078 \\
\hline & Populations - Total & 0.10125 & 100.00 & 0.078 \\
\hline \multirow{3}{*}{ Seed trees } & Populations - Localities & 0.01152 & 7.94 & 0.013 \\
\hline & Localities - Total & 0.13356 & 92.06 & 0.129 \\
\hline & Populations - Total & 0.14508 & 100.00 & 0.141 \\
\hline \multicolumn{5}{|c|}{ b) Conserved vs. exploited forest } \\
\hline \multirow[t]{3}{*}{ Campos do Jordão } & Seed trees - Management & 0.24678 & 100.00 & 0.133 \\
\hline & Management - Total & -0.00550 & 0.00 & -0.003 \\
\hline & Seed trees - Total & 0.24127 & 100.00 & 0.131 \\
\hline \multirow[t]{3}{*}{ Irati } & Seed trees - Management & 0.10851 & 100.00 & 0.116 \\
\hline & Management - Total & -0.00754 & 0.00 & -0.008 \\
\hline & Seed trees - Total & 0.10097 & 100.00 & 0.109 \\
\hline \multirow[t]{3}{*}{ Caçador } & Seed trees - Management & 0.08956 & 95.04 & 0.091 \\
\hline & Management - Total & 0.00468 & 4.96 & 0.005 \\
\hline & Seed trees - Total & 0.09423 & 100.00 & 0.095 \\
\hline \multicolumn{5}{|c|}{ c) Large forest vs. forest islands } \\
\hline \multirow[t]{3}{*}{ Irati } & Seed trees - Forest size & 0.06431 & 95.91 & 0.083 \\
\hline & Forest size - Total & 0.00274 & 4.09 & 0.004 \\
\hline & Seed trees - Total & 0.06705 & 100.00 & 0.087 \\
\hline \multirow[t]{3}{*}{ Caçador } & Seed trees/ Forest size & 0.08439 & 92.60 & 0.096 \\
\hline & Forest size/ total & 0.00674 & 7.40 & 0.008 \\
\hline & Seed trees/ total & 0.09113 & 100.00 & 0.103 \\
\hline \multicolumn{5}{|c|}{ d) Natural forest vs. plantation } \\
\hline \multirow[t]{3}{*}{ Irati } & Seed trees - Management & 0.05615 & 100.00 & 0.066 \\
\hline & Management - Total & -0.00233 & 0.00 & -0.007 \\
\hline & Seed trees - Total & 0.05382 & 100.00 & 0.066 \\
\hline
\end{tabular}

The genetic differentiation among populations within locations based on $F$-statistics is shown in Table 4 . The $F_{S T}$ values are small (0.0042 in Campos do Jordão, 0.0431 in Irati, 0.0478 in Caçador). The mean $F_{I S}$ values are negative for seed-trees in Caçador and Campos do Jordão, and for embryos in all three localities. The analysis of individual loci (not shown here) revealed significant $(\mathrm{P}<0.001)$ negative $F_{I S}$ values for 6 -Pgdh$B$, in embryos, in every population except in a forest (FI-2) of Irati, indicating an excess of heterozygotes at this locus. There was no evidence of inbreeding in adult seed-trees.
The topology of the dendrograms constructed with genetic distances $D$ (NEI, 1972) and $d_{o}$ (GREGORIUS, 1974) between localities were identical (except for scale) distinguishing Campos do Jordão from the other locations. Only those with $d_{o}$ will be presented. Figure 1 shows the dendrogram for seed-trees. The dendrograms in Figure 2 shows populations within Irati and Caçador. In Irati, the largest forest island FI-2 joins with the continuous main forest, followed by the plantation. The exploited forest is the most divergent in this location. In Caçador, the large forest separates from all others and the 
Table 4. - F-statistics combined across loci for populations within localities. Analysis based on maternal genotypes (1) and on embryo genotypes (2)

\begin{tabular}{lcclcrc}
\hline Locality & \multicolumn{3}{c}{ Seed-trees $^{(1)}$} & \multicolumn{3}{c}{ Embryos $^{(2)}$} \\
\cline { 2 - 7 } & $F_{I S}$ & $F_{S T}$ & $F_{I T}$ & $F_{I S}$ & $F_{S T}$ & $F_{I T}$ \\
\hline Campos do Jordão & -0.0403 & 0.0042 & -0.0359 & -0.0359 & 0.0026 & -0.0332 \\
Irati & 0.0274 & 0.0431 & 0.0692 & -0.2120 & 0.0181 & -0.1900 \\
Caçador & -0.1666 & 0.0481 & -0.1105 & -0.1716 & 0.0234 & -0.1442 \\
\hline Mean & -0.0355 & 0.1828 & 0.1538 & -0.0627 & 0.0980 & 0.0414
\end{tabular}

$F_{I S}$ : inbreeding among seed trees within populations; $F_{S T}$ : differences among populations within localities; $F_{I T}$ : total inbreeding within localities.

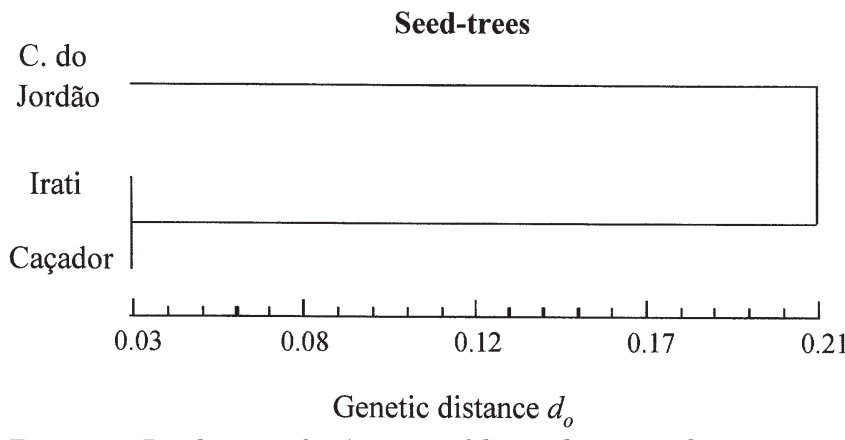

Figure 1. - Dendrogram for A. angustifolia seed-trees in three separate study sites, based on $d_{0}$ and derived by the unweighted pair-group method with arithmetic averaging (UPGMA).

\section{a) Irati Populations}

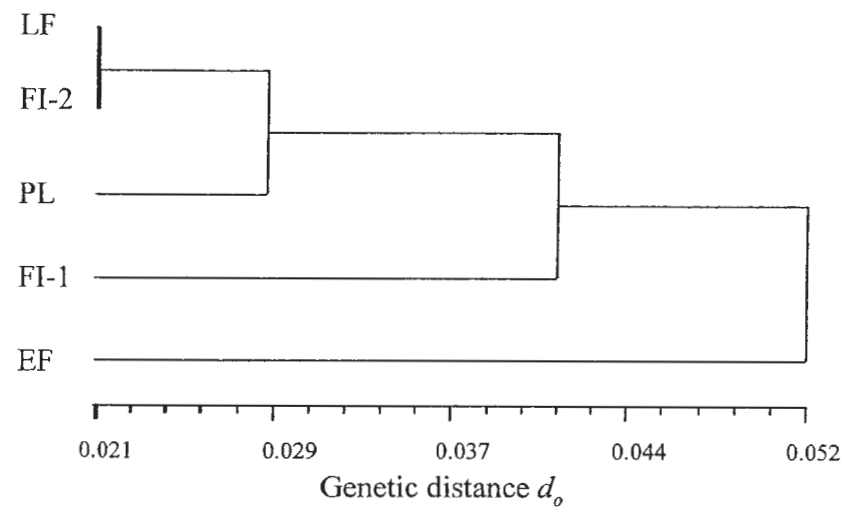

\section{b) Caçador populations}

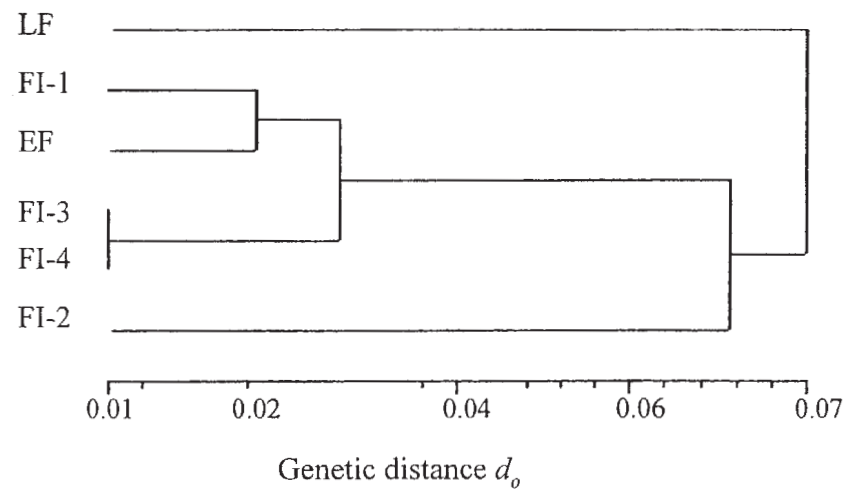

Figure 2. - Dendrograms for A. angustifolia seed-trees based on $d_{o}$ and derived by UPGMA. a) Populations of Irati. b) Populations of Caçador. exploited forest joins the cluster of local forest islands. It is shown in Table 2 that the density of A. angustifolia in the exploited forest is very low. Figure 3 shows snail diagrams representing the population differentiation $D_{j}$ at each locus (except for the non-informative loci Got-C and $S k d h-A$ ). The mean differentiation $\delta$ in $A$. angustifolia ranges from almost zero (Got$C)$ to 0.208 (6-Pgdh-B). The sectors of seed-trees, embryos and pollen in Campos do Jordao indicate high allelic differentiation at all loci. Caçador seed-trees are distinguished by genotypes at $6-P g d h-B$ and $S k d h-B$. Irati populations show low allelic differentiation, except for seed-trees at locus $S k d h-B$. Snail diagrams for seed trees, using pooled loci, are shown in Figure 4. The populations in Campos do Jordão have similar $D_{j}$, with outstanding sectors in all diagrams. Selective logging had less impact in this location than in the exploited forest in Caçador, which shows the overall lowest $D_{j}$. Given the low differentiation of populations outside Campos do Jordão, the exploited forest in Irati and the forest island FI-2 of Caçador are closest to $\delta$.

\section{Sex ratio in the Araucaria forests}

The interpretation of population structure in dioecious species requires information on sex ratios. Table 1 shows the proportions of male, female, and non-reproducing trees counted in the sampling plots. The $\chi^{2}$ test indicates fit to the expected 1:1 sex ratio within each stand. Reproductive maturity is related with age, and consequently, with the distribution of stem diameters in the forest. The population density and the frequency of non-reproducing trees were highest in the large forest of Campos do Jordão. Most of the non-reproducing trees in this forest were young individuals. In contrast, trees not bearing strobili in Forest-Island 2 of Irati $(64.5 \%)$ were mature adults. The average stem diameter of the trees was smallest in Campos do Jordão, intermediate in Irati, and largest in Caçador. The number of non-reproducing trees followed the opposite trend. The overall sex ratio did not differ significantly from 1:1 except in the exploited forest in Campos do Jordão and the large forest in Irati $\left(\chi^{2}=5.54\right.$ and $\chi^{2}=6.54$, respectively) where females were more frequent.

Allelic frequencies and diversity in seed-trees, embryos and effective pollen

Allele frequencies were variable among localities, populations within localities, and between female and male gametic genepools (Tables 5, 6 and 7). The populations in Campos do Jordão show moderate to intermediate frequencies of allele $B_{1}$ of $G o t-B, M d h-B$, and $S k d h-B$ in the seed-trees. These alleles are either absent or rare (5\% or less) in other populations. Allele $B_{1}$ of 6 -Pgdh is either absent or rare in seed-trees, $B_{2}$ predominates in Campos do Jordão ( $\mathrm{LF}$ and $\mathrm{EF}$ ), and $B_{3}$ is the most common allele in all other populations except one. Differences among localities were less pronounced at locus Pgm-A. Variation at loci Got-C and $S k d h-A$ was overall low.

Table 8 shows the $G_{h}$ test for homogeneity in allele frequencies between male and female gametes within populations. Differences in allele frequencies between sexes were statistically significant in about $40 \%$ of the comparisons. In contrast to its absence in seed-trees, allele $B_{1}$ of $S k d h-B$ was represented in the effective pollen in all populations except Irati forest island FI-2, reaching moderate frequencies in six of them. In Campos do Jordão, allele $B_{1}$ of 6 - $P g d h-B$ was more frequent than $B_{3}$ in the effective pollen, and $B_{2}$ was more frequent in seed-trees than in the pollen. The frequencies of alleles $B_{2}$ and $B_{3}$ were more balanced in the pollen in Irati and Caçador. Allele $B_{3}$ of Got- $B$ was found in a single megagametophyte and a single embryo, of separate seeds. 
Got-B

$\delta=0.097$

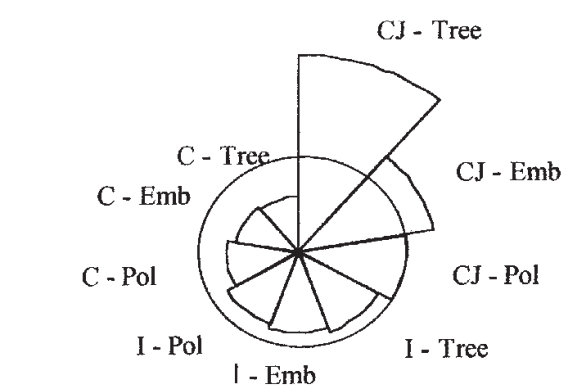

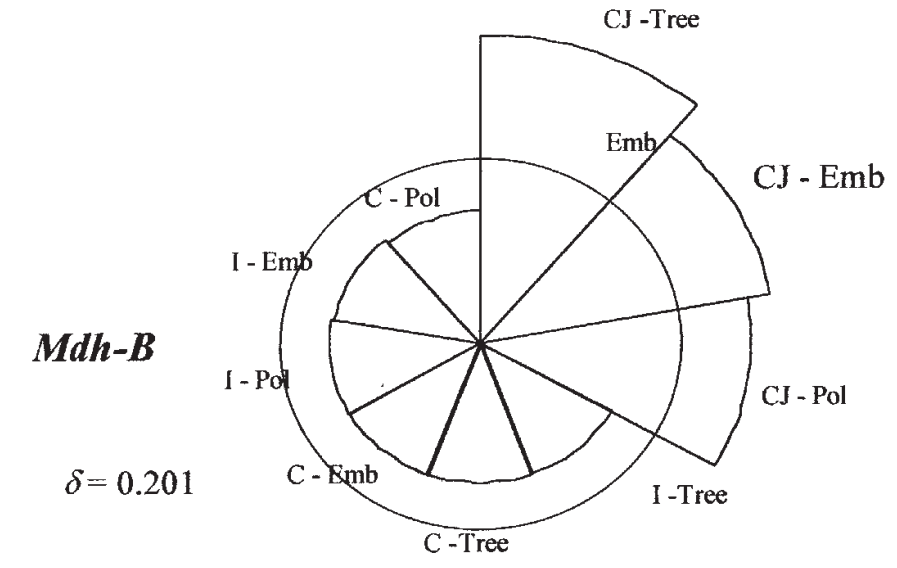
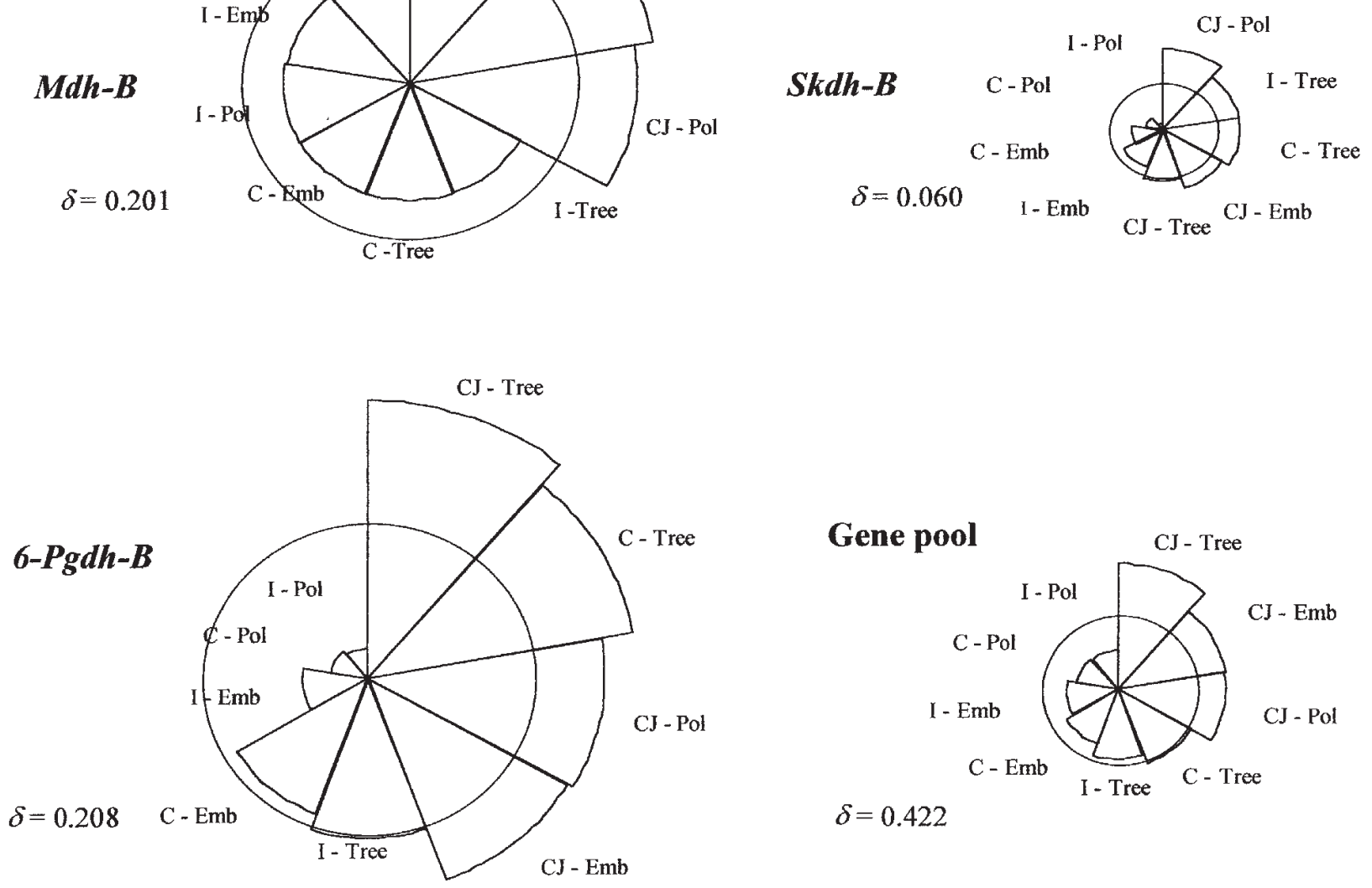

$\delta=0.422$

Figure 3. - Snail diagrams representing the allelic differentiation $\left(D_{j}\right)$ of seed-trees (Tree), embryos (Emb) and effective pollen (Pol) of the populations in Campos do Jordão $(\mathrm{CJ})$, Irati (I), and Caçador $(\mathrm{C})$, compared to the average population differentiation $(\delta)$. Note the larger scale used in this diagram for the gene pool.

The allelic diversity was higher for 6 -Pgdh-B than for other loci, except in the seed-trees of Campos do Jordão populations, where $M d h-B$ alleles had more even frequencies ( $v=1.99$ for the conserved forest and $v=1.92$ for the exploited forest, at $M d h-B)$. The allelic diversity was highest in the effective pollen in Campos do Jordão EF ( $v=1.40$ for pooled loci and $v=2.51$ for 6 -Pgdh-B), given the frequency distribution of the three alleles of $6-P g d h-B$. Allelic diversity with pooled loci was lowest in the Irati FI-2 and Caçador FI-1 seed-trees (both with $v=$ 1.07). The effective pollen was more diverse than the seed-trees and embryos, except in Caçador FI-2.

\section{Discussion}

Genetic diversity and geographic differentiation

The genetic variation at alloenzyme loci in A. angustifolia is lower than the average reported for other conifers, if all 24 loci are considered. In East Asian pines, KIM and LEE (1998) cite $A / L$ ranging from 1.6 in Pinus koraiensis to 3.9 in $P$. thunbergii, $P P L$ values ranging from $43.2 \%$ in Pinus koraiensis to $71.4 \%$ in $P$. sylvestris, and average heterozygosities $H_{o}=0.205$ and $H_{e}=0.211$. For North American conifers, the average expected heterozygosity in 20 conifer species was 0.207 , with 
wide variation among species $\left(H_{e}=0.000\right.$ in Pinus resinosa to $H_{e}=0.341$ in Picea abies) (HAMrICK et al., 1981).

In the present survey, A. angustifolia populations in Brazil were found to be fairly variable in Campos do Jordão, the most northern locality, but less so in Irati and Caçador. Genetic distances between populations within localities were small. The $A$. angustifolia population examined by SHIMIZU et al. (2000) is situated $220 \mathrm{~m}$ above sea level, inside the range of the semi-deciduous forest of the Paraná River. The variability at ten isozyme loci, in needle tissue of 120 trees, was comparable to popula-

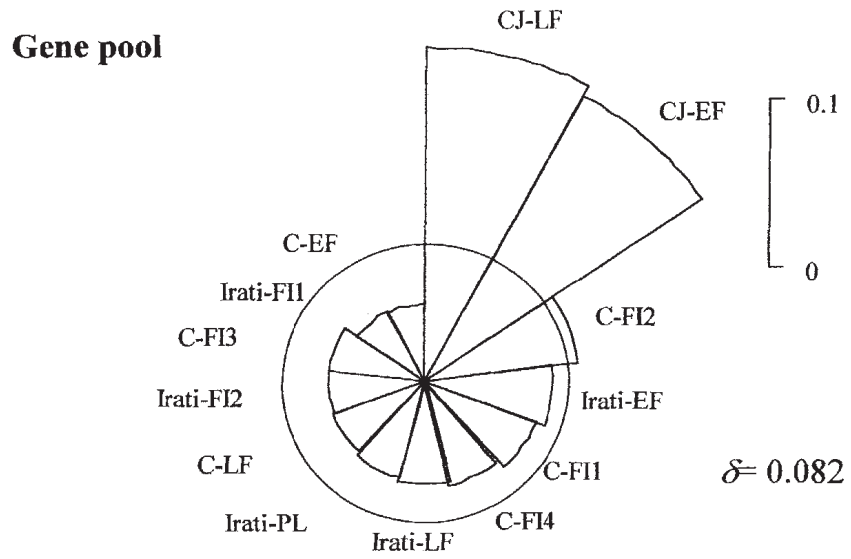

Figure 4. - Snail diagram representing the genetic differentiation $\left(D_{j}\right)$ of populations based on allele frequencies in seed-trees. CJ: Campos do Jordão; I: Irati; C: Caçador; LF: large forest; EF: exploited forest; FI: forest island; PL: plantation.

Note that the scale is different from that in the previous diagram. tions in Campos do Jordão, with slightly higher average number of alleles per locus $\left(A / L=2.3, P P L=80.0, H_{o}=0.240\right.$ and $H_{e}=0.248$ ). AULER et al. (2002) describe the variation at nine isozyme gene loci, from needle tissue of 328 adult trees, representing nine populations of $A$. angustifolia in the Santa Catarina State. Variation was low $\left(A / L=2.0, P P L=26.6, H_{o}=0.073\right.$ and $\left.H_{e}=0.084\right)$ and the genetic differentiation among populations (average $F_{S T}=0.044$ ) was comparable to natural populations in Irati and Caçador. HAMPP et al. (2000) examined 178 seeds of $A$. angustifolia from 13 locations ( 8 to 23 seeds per location), and correlated the presence of a specific DNA sequence with the intensity of the frost events at the geographic origin of the seeds. All together, the geographic variation revealed by alloenzyme and DNA markers align with the palynological evidence of a migration of A. angustifolia, from lowlands in Minas Gerais and São Paulo towards the southern region in Brazil, in the late Pleistocene and early Holocene (KershaW and McGlone, 1995; KershaW and WaGstafF, 2001; BEHLING, 1995; Ledru et al., 1996, De Oliveira and Colinvaux, 1992). According to BEHLING and Lichte (1997), previous cold and dry paleoclimates prevented such range expansion. No Araucaria pollen dating from 35,000 to $17,000{ }^{14} \mathrm{C}$ yr. B.P. was found in Morro de Itaipeva, near Campos do Jordão. The rare representation of Araucaria taxa in this region is more recent, dating from 17,000 to $10,000{ }^{14} \mathrm{C}$ yr. B.P..

\section{Effect of population size}

Selective logging practiced in the exploited forest of Caçador reduced its effective population size, heterozygosity and $v_{\text {gam }}$. compared to the conserved forest. Caçador EF joined with the smaller forest islands in the dendrogram in Figure 2. The exploited forest in Irati diverged from other local populations,

Table 5. - Allelic structures at seven polymorphic loci in Araucaria angustifolia seed-trees sampled in 13 populations.

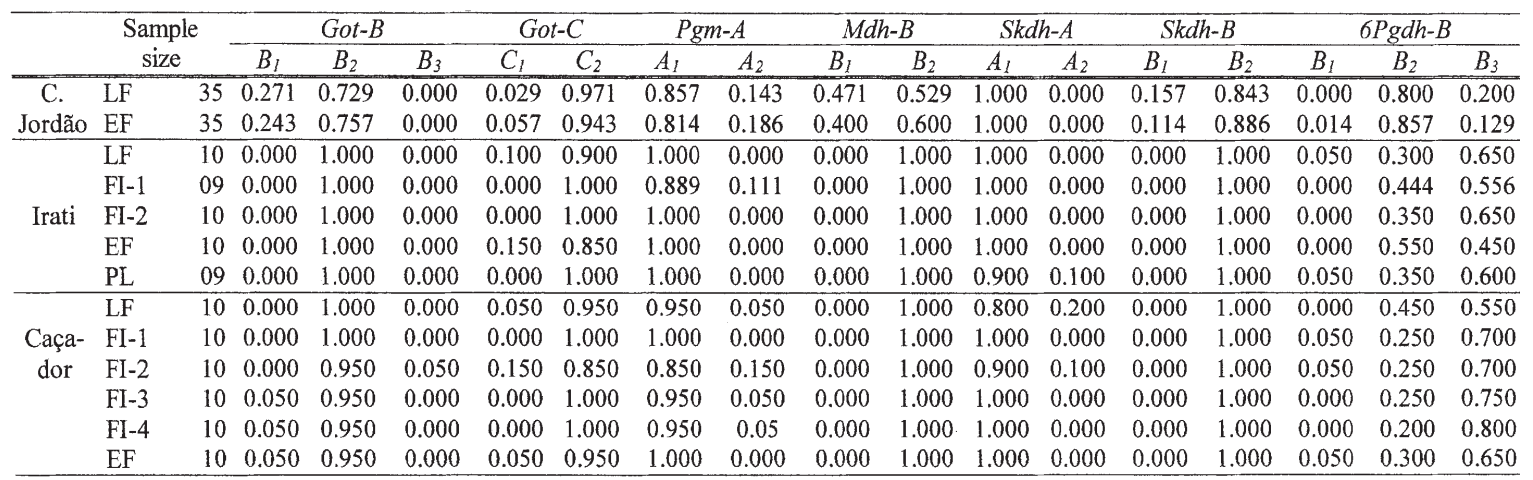

LF = Large Forest; EF = Exploited Forest; PL = Plantation; FI-1, FI-2, FI-3, FI-4 = Forest Islands

Table 6. - Allelic structures at seven polymorphic loci in Araucaria angustifolia embryos sampled in 13 populations

\begin{tabular}{cccccccccccccccccccccc}
\hline & $\begin{array}{c}\text { Sample } \\
\text { size }\end{array}$ & \multicolumn{4}{c}{ Got-B } & $B_{1}$ & $B_{2}$ & $B_{3}$ & $C_{1}$ & $C_{2}$ & $A_{1}$ & $A_{2}$ & $B_{1}$ & $B_{2}$ & $A_{1}$ & $A_{2}$ & $B_{1}$ & $B_{2}$ & $B_{1}$ & $B_{2}$ & $B_{3}$ \\
\hline C. & LF & 680 & 0.191 & 0.808 & 0.001 & 0.022 & 0.978 & 0.871 & 0.129 & 0.424 & 0.576 & 1.000 & 0.000 & 0.173 & 0.827 & 0.158 & 0.681 & 0.160 \\
Jordão & EF & 692 & 0.188 & 0.812 & 0.000 & 0.052 & 0.948 & 0.833 & 0.167 & 0.373 & 0.627 & 0.999 & 0.001 & 0.123 & 0.877 & 0.205 & 0.683 & 0.112 \\
\hline & LF & 80 & 0.006 & 0.988 & 0.006 & 0.075 & 0.925 & 1.000 & 0.000 & 0.013 & 0.988 & 1.000 & 0.000 & 0.106 & 0.894 & 0.112 & 0.381 & 0.506 \\
& FI-1 & 80 & 0.000 & 1.000 & 0.000 & 0.019 & 0.981 & 0.981 & 0.019 & 0.006 & 0.994 & 1.000 & 0.000 & 0.025 & 0.975 & 0.062 & 0.506 & 0.431 \\
Irati & FI-2 & 80 & 0.000 & 1.000 & 0.000 & 0.000 & 1.000 & 1.000 & 0.000 & 0.000 & 1.000 & 1.000 & 0.000 & 0.000 & 1.000 & 0.057 & 0.462 & 0.481 \\
& EF & 79 & 0.006 & 0.994 & 0.000 & 0.125 & 0.875 & 0.931 & 0.069 & 0.000 & 1.000 & 0.994 & 0.006 & 0.006 & 0.994 & 0.100 & 0.444 & 0.456 \\
& PL & 72 & 0.000 & 1.000 & 0.000 & 0.013 & 0.988 & 1.000 & 0.000 & 0.000 & 1.000 & 0.894 & 0.106 & 0.038 & 0.962 & 0.094 & 0.456 & 0.450 \\
\hline & LF & 80 & 0.006 & 0.994 & 0.000 & 0.013 & 0.988 & 0.938 & 0.062 & 0.000 & 1.000 & 0.837 & 0.162 & 0.062 & 0.938 & 0.081 & 0.450 & 0.469 \\
Caça- & FI-1 & 80 & 0.000 & 1.000 & 0.000 & 0.019 & 0.981 & 1.000 & 0.000 & 0.006 & 0.994 & 1.000 & 0.000 & 0.000 & 1.000 & 0.082 & 0.399 & 0.519 \\
dor & FI-2 & 80 & 0.019 & 0.975 & 0.006 & 0.071 & 0.929 & 0.894 & 0.106 & 0.000 & 1.000 & 0.962 & 0.038 & 0.006 & 0.994 & 0.082 & 0.348 & 0.570 \\
& FI-3 & 75 & 0.054 & 0.946 & 0.000 & 0.013 & 0.987 & 0.962 & 0.038 & 0.000 & 1.000 & 1.000 & 0.000 & 0.031 & 0.969 & 0.031 & 0.356 & 0.613 \\
& FI-4 & 79 & 0.044 & 0.956 & 0.000 & 0.006 & 0.994 & 0.962 & 0.038 & 0.000 & 1.000 & 0.994 & 0.006 & 0.081 & 0.919 & 0.062 & 0.294 & 0.644 \\
& EF & 79 & 0.006 & 0.994 & 0.000 & 0.032 & 0.968 & 1.000 & 0.000 & 0.000 & 1.000 & 0.994 & 0.006 & 0.108 & 0.892 & 0.051 & 0.392 & 0.557 \\
\hline
\end{tabular}

LF = Large Forest; EF = Exploited Forest; PL = Plantation; FI-1, FI-2, FI-3, FI-4 = Forest Islands 
Table 7. - Allelic structures at seven polymorphic loci in Araucaria angustifolia effective pollen sampled in 13 populations.

\begin{tabular}{|c|c|c|c|c|c|c|c|c|c|c|c|c|c|c|c|c|c|c|}
\hline & \multirow{2}{*}{\multicolumn{2}{|c|}{$\begin{array}{c}\begin{array}{c}\text { Sample } \\
\text { size }\end{array} \\
\end{array}$}} & \multicolumn{3}{|c|}{ Got $-B$} & \multicolumn{2}{|c|}{ Got-C } & \multicolumn{2}{|c|}{$P g m-A$} & \multicolumn{2}{|c|}{$M d h-B$} & \multicolumn{2}{|c|}{$S k d h-A$} & \multicolumn{2}{|c|}{$S k d h-B$} & \multicolumn{3}{|c|}{$6 P g d h-B$} \\
\hline & & & $B_{1}$ & $B_{2}$ & $B_{3}$ & $C_{1}$ & $C_{2}$ & $A_{1}$ & $A_{2}$ & $B_{1}$ & $B_{2}$ & $A_{I}$ & $A_{2}$ & $B_{1}$ & $B_{2}$ & $B_{l}$ & $B_{2}$ & $B_{3}$ \\
\hline S & LF & 680 & 0.159 & 0.840 & 0.001 & 0.016 & 0.984 & 0.871 & 0.129 & 0.389 & 0.611 & 1.000 & 0.000 & 0.193 & 0.807 & 0.314 & 0.556 & 0.130 \\
\hline Jordão & EF & 692 & 0.173 & 0.827 & 0.000 & 0.052 & 0.948 & 0.830 & 0.170 & 0.367 & 0.633 & 0.999 & 0.001 & 0.146 & 0.854 & 0.408 & 0.466 & 0.126 \\
\hline \multirow{5}{*}{ Irati } & LF & 80 & 0.013 & 0.975 & 0.013 & 0.012 & 0.988 & 1.000 & 0.000 & 0.025 & 0.975 & 1.000 & 0.000 & 0.212 & 0.788 & 0.162 & 0.500 & 0.337 \\
\hline & FI-1 & 80 & 0.000 & 1.000 & 0.000 & 0.038 & 0.962 & 0.962 & 0.038 & 0.013 & 0.988 & 1.000 & 0.000 & 0.050 & 0.950 & 0.125 & 0.500 & 0.375 \\
\hline & FI-2 & 80 & 0.000 & 1.000 & 0.000 & 0.000 & 1.000 & 1.000 & 0.000 & 0.000 & 1.000 & 1.000 & 0.000 & 0.000 & 1.000 & 0.114 & 0.544 & 0.342 \\
\hline & EF & 79 & 0.013 & 0.987 & 0.000 & 0.087 & 0.913 & 0.962 & 0.038 & 0.000 & 1.000 & 0.988 & 0.013 & 0.013 & 0.988 & 0.200 & 0.375 & 0.425 \\
\hline & PL & 72 & 0.000 & 1.000 & 0.000 & 0.025 & 0.975 & 1.000 & 0.000 & 0.000 & 1.000 & 0.888 & 0.112 & 0.075 & 0.925 & 0.137 & 0.525 & 0.337 \\
\hline \multirow{6}{*}{$\begin{array}{l}\text { Caça- } \\
\text { dor }\end{array}$} & LF & 80 & 0.013 & 0.988 & 0.000 & 0.000 & 1.000 & 0.925 & 0.075 & 0.000 & 1.000 & 0.850 & 0.150 & 0.125 & 0.875 & 0.162 & 0.363 & 0.475 \\
\hline & FI-1 & 80 & 0.000 & 1.000 & 0.000 & 0.038 & 0.962 & 1.000 & 0.000 & 0.013 & 0.988 & 1.000 & 0.000 & 0.000 & 1.000 & 0.114 & 0.557 & 0.329 \\
\hline & FI-2 & 80 & 0.038 & 0.962 & 0.000 & 0.026 & 0.974 & 0.938 & 0.062 & 0.000 & 1.000 & 1.000 & 0.000 & 0.013 & 0.988 & 0.101 & 0.430 & 0.468 \\
\hline & FI-3 & 74 & 0.027 & 0.973 & 0.000 & 0.026 & 0.974 & 0.975 & 0.025 & 0.000 & 1.000 & 1.000 & 0.000 & 0.062 & 0.938 & 0.062 & 0.500 & 0.437 \\
\hline & FI-4 & 79 & 0.013 & 0.987 & 0.000 & 0.013 & 0.988 & 0.988 & 0.013 & 0.000 & 1.000 & 0.988 & 0.013 & 0.162 & 0.837 & 0.125 & 0.375 & 0.500 \\
\hline & $\mathrm{EF}$ & 79 & 0.000 & 1.000 & 0.000 & 0.051 & 0.949 & 1.000 & 0.000 & 0.000 & 1.000 & 0.987 & 0.013 & 0.215 & 0.785 & 0.063 & 0.544 & 0.392 \\
\hline
\end{tabular}

LF $=$ Large Forest; EF = Exploited Forest; PL = Plantation; FI-1, FI-2, FI-3, FI-4 = Forest Islands

$\mathrm{N}=$ sample size

Table 8. - Homogeneity test ( $G_{h}$ test) of allelic frequencies between male and female gametes in 13 populations of Araucaria angustifolia. Data of effective pollen and megagametophytes.

\begin{tabular}{llccccccc}
\hline Locality & Pop. & Got-B & Got-C & Pgm-A & Mdh-A & Skdh-A & Skdh-B & $6 P g d h-B$ \\
\hline C. & LF & $8.800^{* *}$ & 4.084 & 0.006 & $6.832^{* *}$ & --- & $3.956^{* *}$ & $103.100^{* * *}$ \\
Jordão & EF & 1.896 & 0.000 & 0.082 & 0.197 & 1.387 & $6.217^{*}$ & $103.100^{* * *}$ \\
\hline \multirow{6}{*}{ Irati } & LF & 2.798 & $10.428^{* *}$ & --- & 2.798 & --- & $25.593^{* * *}$ & $9.687^{* *}$ \\
& FI-1 & --- & $4.216^{*}$ & 1.752 & 1.393 & --- & $5.648^{*}$ & 0.025 \\
& FI-2 & --- & --- & -- & --- & --- & --- & 4.324 \\
& EF & 1.393 & 2.085 & $4.216^{*}$ & --- & 1.393 & 1.393 & 3.034. \\
& PL & --- & 2.798 & --- & --- & 0.066 & $8.552^{* *}$ & 3.058 \\
\hline \multirow{6}{*}{ Caçador } & LF & 1.393 & 2.798 & 0.098 & & 0.184 & $14.530^{* *}$ & $4.796^{* *}$ \\
& FI-1 & --- & $4.216^{*}$ & -- & 1.393 & --- & -- & $16.856^{* * *}$ \\
& FI-2 & 5.571 & $5.156^{* *}$ & 3.313 & --- & $8.552^{* *}$ & 1.393 & $6.989^{*}$ \\
& FI-3 & 2.150 & 2.826 & 0.706 & --- & --- & $7.093^{* *}$ & $14.730^{* * *}$ \\
& FI-4 & $4.128^{*}$ & 1.393 & 3.015 & --- & 1.393 & $19.173^{* * *}$ & $5.142^{*}$ \\
& EF & 1.393 & 1.986 & --- & --- & 1.393 & $25.622^{* *}$ & $15.602^{* *}$ \\
\hline
\end{tabular}

$\mathrm{LF}=$ Large Forest EF = Exploited Forest; PL = Plantation;

FI-1, FI-2, FI-3, FI-4 = Forest Islands

Levels of significance: $* \mathrm{P}<0.050, * * \mathrm{P}<0.010$ and $* * * \mathrm{P}<0.001$

in this case because of unique genotypes (Figures 2 and 3). Irati $\mathrm{EF}$ also has the overall lowest density of A. angustifolia trees among the 13 populations. Forest exploitation had less effect in the forest in Campos do Jordão, where genetic variability and tree density were higher. Comparing preharvest and postharvest gene pools in old-growth stands of Pinus strobus in central Ontario, BucHERT et al. (1997) observed that approximately $25 \%$ of alloenzyme alleles were lost, and the percentage polymorphic loci dropped by about $33 \%$, after tree density reduction of $75 \%$. Gene flow is reported to be very high in this species. In contrast, the genetic differentiation among single-tree progenies in Campos do Jordão revealed that a small percentage of the male trees participated effectively in the pollination. Consequently, there are lower chances that genetic diversity in exploited forests will be restored by pollen migration from surrounding populations in A. angustifolia than in Pinus strobus. Pollen grains of A. angustifolia do not possess wind sacs and are relatively large $(61.5 \mu \mathrm{m})$ compared to the average pollen size of other anemophilous species (SouZA and HATTEMER, 2003). Also, the heavy seeds of A. angustifolia are dispersed by autochory and concentrate near the mothertree (CARVALHo, 1994). Foraging animals (rodents, domestic pigs, peccaries, and jays) promote secondary dispersion of the seeds (MÜller, 1990; CARVAlHo, 1994; ENRIGHT et al., 1995). In consequence of habitat fragmentation, large carnivores have disappeared and the populations of small rodents have increased substantially. Higher proportions of seeds are predated, thus reducing the species regeneration capacity.
Sex ratio and genetic differentiation of female and male gene-pools

Sex ratio was 1:1 in the large forest in Caçador, the oldest and most exuberant population included in our study. Balanced sex ratio was also observed in another 10 ha sampling plot studied in the large forest of Campos do Jordão (SolóRZANo, 2001). Female trees were more frequent in the exploited forest of Campos do Jordão and in the large forest in Irati. In contrast, excess of male trees were observed in some natural and planted A. angustifolia forests (PINTO, 1982; BANDEL, 1983), showing that the deviations from the 1:1 ratio are not sexbiased in adult trees. Occasional monoecious A. angustifolia specimens are reported and considered an abnormality associated with fungal infection (Uleiella paradoxa) of male strobili, or physical damage to the tree (REITZ and KLEIN, 1966; SHIMIZU and OLIVEIRA, 1983).

In spite of balanced sex ratio, female and male A. angustifolia gene pools differed significantly in allelic structure at loci $S k d h-B$ and 6 -Pgdh-B. This difference explains the higher heterozygosities and the negative $F_{I S}$ values found for embryos (Tables 2 and 4). Gene loci of 6-Pgdh are related to sex expression in several dioecious plants, with a particular allele being unique to one of the sexes (SCHNABEL and HAMrick, 1990). In $A$. angustifolia, the allele $B_{1}$ of $6-P g d h-B$ is rare, but not absent, in the female gamete-pool. Meiotic segregation distortion was observed in some trees, yet mostly for Got-B (SousA et al., 2002). For $6-P g d h-B$, the single heterozygote $B_{1} B_{2}$ seed-tree found in the Campos do Jordão EF produced one $B_{1}$ and nineteen $B_{2}$ megagametophytes in a sample of 20 seeds. The connection between the observed segregation distortion and the rarity of the $B_{1}$ allele in seed-trees needs further investigation.

The genic diversity was highest in the effective pollen in all 13 populations. It averaged 1.186 , exceeding by 3 percent the value estimated for seed trees (1.146), that of embryos falling in between (1.170). One may be tempted to attribute these results to the larger number of pollen-contributing males than sampled seed trees. However, these results are due to the larger average diversity present at locus $6-P g d h-B$ in the males (values ranging from 2.201 to 2.768), significantly exceeding that in the seed trees (values ranging from 1.331 to 2.062) (SOUSA, 2001).

\section{References}

Auler, N. M. F., Reis, M. S., Guerra, M. P. and Nodari, R. O.: The genetics and conservation of Araucaria angustifolia: 1. Genetic structure and diversity of natural populations by means of non-adaptive 
variation in the state of Santa Catarina, Brazil. Genetics and Molecular Biology: 25 (3), 329-338 (2002). - BANDEL, G.: Proporção do sexo em pinheiro brasileiro. Araucaria angustifolia (Bert.) O. Ktze. Silvicultura 8, 238-240 (1983). - BEHLING, H.: Investigations into the Late Pleistocene and Holocene history of vegetation and climate in Santa Catarina (S. Brazil). Vegetation History and Archeobotany 4, 127-152 (1995). - Behling, H. and Lichte, M.: Evidence of dry and cold climatic conditions at glacial times in tropical southeastern Brazil. Quaternary Research 48, 348-358 (1997). - Buchert, G. P., RAJora, O. P., HoOD, J.V. and DANCIK, B. P.: Effects of harvesting on genetic diversity in oldgrowth eastern white pine in Ontario, Canada. Conserv. Biol. 11, 747-758 (1997). - CARVAlHo, P. E. R.: Espécies florestais brasileiras. Recomendações silviculturais, potencialidades e uso da madeira. EMBRAPA-CNP Florestas, Colombo, 639 p. (1994). - CROcE, D. M. Caracterização especial, estrutural e fitossociológica da reserva genética de Caçador. MS Dissertation, Universidade Federal de Santa Maria Santa Maria, 120 p. (1991). - CROw, J. F. and KIMURA, M.: An Introduction to Population Genetics Theory. New York: Harper and Row, $591 \mathrm{p}$ (1970). - De Oliveira, P. E. and Colinvaux, P. A.: Vegetational and climatic changes of the late Quaternary in southeastern Brazil. $8^{\text {th }}$ International Palynological Congress Programme and Abstracts, Aix-enProvence, 34 p. (1992). - Enright, N. J., Hill, R. S. and Veblen, T. T. The Southern Conifers. An Introduction. P. 1-9. In: EnRIGHT, N. J. and HiLL, R. S. (eds.): Ecology of the Southern Conifers. Melbourne: Melbourne University Press, 342 p. (1995). - FÄHSER, L.: Die Bewirtschaftung der letzten Brasil-Kiefer-Naturwälder, eine entwicklungspolitische Aufgabe. Forstarchiv 52, 22-26 (1981). — FAVRIN, L. J. B.: Levantamen to da cobertura vegetal do município de Campos do Jordão no período de 1962 a 1977, através de fotografias aéreas. Silvicultura em São Paulo, 17/19: 39-45 (1983/85). - Giannotti, E., Timoni, J. L, Mariano, G. Coelho, L. C. C., Fontes, M. A. and Kageyama, P. Y.: Variação genética entre procedências e progênies de Araucaria angustifolia (Bert) O. Ktze. Silvicultura em S. Paulo 16 A (Pt2), 970-975 (1982). — Gillet, E. M. GSED. Genetic Structures from Electrophoresis Data, Version 1.1 User's Manual. Institut für Forstgenetik und Forstpflanzenzüchtung, Universität Göttingen (1998). http://www.uni-forst.gwdg.de/forst/ fg/index.htm. - GREGORIUs, H.-R.: Genetischer Abstand zwischen Populationen. I. Zur Konzeption der genetischen Abstandsmessung. Silvae Genetica 23, 22-27 (1974). - GREGORIUs, H.-R.: The concept of genetic diversity and its formal relationship to heterozygosity and genetic distance. Math. Bioscience 41, 253-271 (1978). — GREGORIUS, H.-R.: Measurement of genetic differentiation in plant populations. P. 276-285. In: Gregorius, H.-R. (ed.): Population Genetics in Forestry. Berlin: Springer-Verlag (1985). - GREGORIUS, H. -R.: The relationship between the concepts of genetic diversity and differentiation. Theoret. Appl. Genet. 74, 397-401 (1987). — Gregorius, H.-R. and RoBERDS, J. H.: Measurement of genetical differentiation among subpopulations. Theoret. Appl. Genet. 71, 826-834 (1986). — GuberT FilHo, F. A.: Proposta para a criação de um sistema de unidade de conservação de Araucaria angustifolia no Estado do Paraná. Instituto de Terras, Cartografia Florestas, 34 p. (1989). - Gurgel, J. T. A. and Gurgel Filho, O. A. Evidências de raças geográficas no pinheiro brasileiro, Araucaria angustifolia (Bert.) O. Ktze. Ciência e Cultura 17, 33-39 (1965). Hampr, R., Mertz, A., Schaible, R. and Schwaigerer, M.: Distinction of Araucaria angustifolia seeds from different locations in Brazil by a specific DNA sequence. Trees 14: 429-434 (2000). - HAMrick, J. L., MiTTON, J. B. and LINHART, Y. B.: Levels of genetic variation in trees: influence of the life history characteristics. P. 35-41. In: ConkLE (ed.): Proc Symp. North American Forest Trees and Insects. USDA For. Serv. General Tech. Rep. PSW-48 (1981). - HUECK, K.: Die Wälder Südamerikas. Stuttgart: Fischer-Verlag (1966). - KAGEYAMA, P. Y. and JACOB, W. S. Variação genética entre e dentro de populações de Araucaria angustifolia (Bert) O. Ktze. Circular Técnica IPEF 115, 8 p. (1980). - KershaW,
A. P. and McGlone, M. S.: The quaternary history of the southern conifers. P. 30-64. In: ENRIGHT, N. J. and HiLl, R. S. (eds.): Ecology of the Southern Conifers. Melbourne: Melbourne University Press, $342 \mathrm{p}$. (1995). - Kershaw, P. and WagstafF, B.: The southern conifer family Araucariaceae: history, status, and value for paleoenvironmental reconstruction. Annual Review of Ecology and Systematics 32, 397-414 (2001). - KIM, Z. S and LEE, S. W.: Genetic diversity in East-Asian Pinus species. P. 205-219. In: PURI, S. (ed.): Tree Improvement. Applied Research and Technology Transfer. New Hampshire: Science Publishers, Inc. (1998). - KleIN, R. M.: O aspécto dinâmico do pinheiro brasileiro. Sellowia 12, 17-44 (1960). - KLEIN, R. M.: Os tipos florestais com Araucaria em Santa Catarina. Anais do XXXVI Congresso Nacional de Botanica do Brasil, Curitiba, 1985, Vol. 1. IBAMA, Brasilia (1990). - Ledru, M. P., Braga, P. I. S., Soubies, F., Fournier, M., MarTin, L., Suguio, K. and TurcQ, B.: The last 50,000 years in the neotropics (southern Brazil): Evolution of vegetation and climate. Palaeogeography Palaeoclimatology Palaeoecology 123, 239-257 (1996). — MATTos, J. R.: O Pinheiro Brasileiro. Anuário Agrícola, Suplemento de Chácaras e Quintais, 239-250 (1965) - MAZZA, M. C. M.: Use of RAPD markers in the study of genetic diversity of Araucaria angustifolia (BERT.) populations in Brazil. P. 103-111. In: BRuns, S., MANTELL, S. and TraghardH Viana, A. M. (eds.): Recent Advances in Biotechnologiy for Tree Conservation and Management. Stockholm: International Foundation for Science (1997). - Monteiro, R. F. R., Speltz, R. M. and GuRgel, J. T. A.: Comportamento silvicultural de 24 raças geográficas de Araucaria angustifolia (Bert.) O. Ktze. no Paraná. Silvicultura em S. Paulo. 16 A (Pf.2), 814-824 (1982). - MülleR, J. A.: A influência dos roedores e aves na regeneração da Araucaria angustifolia (Bert.) O. Ktze. Floresta 20, 45-46 (1990). - NEI, M.: Genetic distance between populations. Amer. Nat. 106, 283-292 (1972). — NEI, M.: Analysis of gene diversity in subdividided populations. Proc. Nat. Acad. Sci. USA 70, 3321-3323 (1973). - PINTO, S. A. A.: Influência da dioicia no diâmetro e na altura de Araucaria angustifolia (Bert.) O. KTZE. e suas implicações na formação de áreas de produção de sementes na região de Quedas do Iguaç-Estado do Paraná. Silvicultura 7, 44 (1982). — REITZ, R. P. and Klein, R. M.: Flora Ilustrada Catarinense. Araucariáceas. Itajaí, 62 p. (1966). - SchNABEL, A. and HAMRICK, J. L.: Nonrandom associations between sex and 6-phosphogluconate dehydrogenase isozyme genotypes in Gleditsia triacanthos L. The Journal of Heredity 81, 230-233 (1990). - SHIMiZU, J.Y.: Variacão entre procedências de araucária em Ribeirão Branco (SP) aos 23 anos de idade. Boletim de Pesquisa Florestal, Colombo, n. 38, 89-102 (1999). - SHIMIZU, J. Y. and Oliveira, Y. M. M.: Distribution, variation and uses of Araucaria gene resources in Southern Brazil. Silvicultura 30, 287-90 (1983). SHIMIZU, J. Y., JAEGER, P. and SoPCHAKI, S. A.: Variabilidade genética em uma populacão remanescente de Araucária no Parque Nacional do Iguaçu, Brasil. Boletim de Pesquisa Florestal, Colombo, n. 41, 18-32 (2000). - SolóRzano Filho, J. A.: Demografia, fenologia e ecologia da dispersão de sementes de Araucaria angustifolia (Bert.) Kuntze (Araucariaceae), numa população relictual em Campos do Jordão, SP. Dissertação de Mestrado. Instituto de Biociências da Universidade de São Paulo, São Paulo, 155 p. (2001). — SousA, V. A., HATTEMER, H. H.: Pollen dispersal and gene flow by pollen in populations of Araucaria angustifolia. Aust. J. Bot. 51, 309-317 (2003). - Sousa, V. A., Hattemer, H. H. and Robinson, I. P.: Inheritance and linkage relationships of isozyme variants of Araucaria angustifolia (BERT.) O. KTZE. Silvae Genetica 51, 191-196 (2002). - SwofFord, D. L. and SELANDER, R. B.: BIOSYS-2. A Computer Program for the Analysis of Allelic Variation in Genetics. User's Manual. (1997). - WRIGHT, S.: The genetical structure of populations. Ann. Eugenics 15, 323-354 (1951). - WRIGHT, S.: The interpretation of population structure by $F$-statistics with special regard to systems of mating. Evolution 19, 395-420 (1965). 